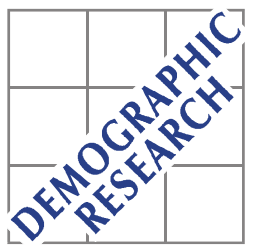

Demographic Research a free, expedited, online journal

of peer-reviewed research and commentary in the population sciences published by the Max Planck Institute for Demographic Research

Konrad-Zuse Str. 1, D-18057 Rostock · GERMANY

www.demographic-research.org

DEMOGRAPHIC RESEARCH

VOLUME 17, ARTICLE 19, PAGES 567-590

PUBLISHED 20 DECEMBER 2007

http://www.demographic-research.org/Volumes/Vol17/19/

DOI: 10.4054/DemRes.2007.17.19

Reflexion

Family change and migration in the life course: An introduction

\title{
Hill Kulu
}

\section{Nadja Milewski}

Special Collection 6: Interdependencies in the Life Course, edited by Hill Kulu and Nadja Milewski.

(C) 2007 Kulu \& Milewski

This open-access work is published under the terms of the Creative Commons Attribution NonCommercial License 2.0 Germany, which permits use, reproduction \& distribution in any medium for non-commercial purposes, provided the original author(s) and source are given credit.

See http:// creativecommons.org/licenses/by-nc/2.0/de/ 


\section{Table of Contents}

1 Introduction: the life-course approach $\quad 568$

$2 \quad$ Previous research on interdependencies between 570

$2.1 \quad$ The effect of family change on internal migration and 570

$2.2 \quad$ The effect of migration on childbearing 573

3 The contributions to the special collection of 575

Demographic Research

$\begin{array}{lll}4 & \text { Conclusion } & 579\end{array}$

5 Acknowledgements 582

References $\quad 583$ 


\title{
Family change and migration in the life course: An introduction
}

\author{
Hill Kulu ${ }^{1}$ \\ Nadja Milewski ${ }^{2}$
}

\begin{abstract}
This article is an introduction to Special Collection 6 of Demographic Research whose articles investigate the interrelations between the family and migration behaviour of individuals in industrialised countries. We first review the life-course approach and previous research on the interplay between family change and migration. We then describe the contribution of the articles in the collection. This is followed by a discussion of selected issues raised in the papers and an outline of future research avenues. We argue that the life-course approach and event-history analysis offer a fruitful framework to examine how individuals simultaneously structure their family lives and residential trajectories, and thus shape demographic change in society.
\end{abstract}

\footnotetext{
${ }^{1}$ Max Planck Institute for Demographic Research, Konrad-Zuse-Straße 1, 18057 Rostock, Germany. E-mail: kulu@ demogr.mpg.de

${ }^{2}$ Institut national d'études démographiques, 133, boulevard Davout, 75020 Paris, France.

E-mail: nadja.milewski@ined.fr
} 


\section{Introduction: the life-course approach}

The history of life-course studies can be traced back to the research activities of the Chicago school of sociology in the early 20th century. Inspired by a study of Thomas and Znaniecki on Polish peasants in Europe and America (1918-20), researchers began to use life records to study social change and the life trajectories of individuals (Elder 1985b: 24). The life-course approach in its current form emerged in the 1960s as a result of developments in theory, data resources, and methods (Elder 1985a: 15-16). First, radical social change during the decade prompted new questions on the relationship between an individual's life history, the cohort, and the historical context. The outcome of this context, intellectual in nature, and of studies on aging, social mobility, and social biography was the concept of the life course (cf. Mayer and Tuma 1990: 7). Second, data sources became available to meet the needs of the life-course approach (Duncan and Morgan 1985). While longitudinal studies in the 1960s were usually launched without theoretical knowledge of the life course, their findings had important implications for research (Elder 1985b: 24). Third, the techniques of lifecourse analysis were developed, beginning with simple causal models and path analysis and then moving to complex event-history analysis (starting with Hoem 1970, Cox 1972).

The life-course approach has developed over four decades and has become a research paradigm in many areas of social sciences. According to this approach, an individual's life is composed of a series of transitions or life events, which are embedded in trajectories or careers (or status passages) that give them a distinct form and meaning (Elder 1985b: 31, Elder 1994: 5, Marshall and Mueller 2003: 18). The life-course approach examines life trajectories of individuals with the aim of explaining their movements between various statuses and roles. While individual life events and patterns of life trajectories are the focus of empirical analysis, the wider objective is to explain and understand social change and social phenomena (Mayer and Tuma 1990: 45). Needless to add that an individual's life course itself is embedded in social institutions and that it is subject to historical forces and cohort pressures, among other factors (Elder 1985a: 15). In their review of the life-course approach, Giele and Elder (1998) identify four key factors that determine the shape of an individual's life course: human agency, linked lives (social relations), historical and geographical context, and the timing of life events (Giele and Elder 1998: 8-11).

At least two methodological features, taken together, give the life-course approach its own character, and make it distinct from other approaches in the social sciences. The first, methodological individualism, states that social phenomena emerge from interactions of individual agents; so, to explain social change we need to explain individual actions (Elster 1989: 13, Hollis 1996: 358). The second dimension, equally 
important, is the dynamic approach to human life. Most contemporary perspectives emphasise the importance of human agency, social relations, and context when explaining individual action (see Bourdieu 1977, Giddens 1984). However, the explicit focus on the timing of events in one life domain of an individual relative to changes in other life domains and changes in social relations and context provides the life-course perspective with the advantage of advancing our knowledge of the causes of individuals' actions and social processes (cf. Giele and Elder 1998: 10).

The life-course approach thus focuses on an individual's activity and explicitly deals with its dynamic nature. As a methodological framework it is open to various theories that explain human actions and social phenomena. Researchers have argued that the life-course approach emerged in the 1960s in order to understand social change from a non-Marxist perspective (White Riley 1998). If true, ironically, the approach itself offers an appropriate micro-level framework to examine whether or not, and if so, the extent to which class structure and class consciousness determine the life trajectories of individuals (cf. Wright 1997). In fact, structuralist accounts of the life course are not rare in the literature. While Anglo-American researchers of life-course dynamics tend to emphasise the importance of the interaction between markets, social networks, and individual decisions in shaping the life course of individuals, many European researchers stress the critical role played by the social structure, particularly the state 'as a distal force', in determining the life-course outcomes of individuals (Marshall and Mueller 2003: 23, Settersten and Gannon 2005: 49-50, see also EspingAndersen 1990, Leisering and Schumann 2003).

The view that life events are a cornerstone in human life has made the life-course approach attractive to population researchers and explains why the perspective has become increasingly popular in population studies (Dykstra and van Wissen 1999). Demographers have traditionally focused on describing and explaining the most important life events and they have developed powerful tools for such analyses. The recent 'life-course turn' has persuaded population researchers to move beyond conventional techniques of analysis based on simplified assumptions (such as the homogeneity of (sub)populations, the independence of life events in one domain from events in other domains and from the past) and to adopt methods that take into account the complexity and dynamic nature of individual life histories. Event-history analysis is such a technique as it allows to link events in one life domain of an individual to past events in the same domain, to changes in other life domains of the same individual ('parallel careers'), and to changes in the life of other family members and members of the individual's social networks ('linked lives') (cf. Hoem 1987, 1993a, Courgeau and Lelievre 1989, Yamaguchi 1991, Blossfeld and Rohwer 1995, Willekens 1999; see also Billari 2005). It thus significantly advances our understanding of the causes of an individual's actions. Recently, the conventional approach has been extended to 
multilevel event-history analysis in order to examine simultaneously the effect of changing individual, family, and social contexts on the actions of individuals (Courgeau 1998, Hoem 2007: 54).

In population studies, a large body of the recent family and fertility research examines how changes in the educational and occupational careers of individuals influence their partnership and childbearing patterns (Hoem 1997, Andersson 2000, Kravdal 2001, Kreyenfeld 2002, Kantorová 2004, Hoem et al. 2006a, 2006b). The same is true for studies of internal and international migration, where changes in educational and occupational domains are considered as major reasons why individuals decide to change their region or country of residence (Wagner 1990, Öberg 1996, Castles and Miller 1998, Détang-Dessendre and Molho 1999, Kulu and Billari 2006, cf. Massey and Espinosa 1997). The articles in this Special Collection of Demographic Research focus on the interaction between the family and the migration careers of individuals. We examine how changes in the family domain lead to changes in residence and we study how migration influences individual fertility and family behaviour. All articles are revised versions of papers presented at the workshop Interdependencies in the Life Course: Family Dynamics, Childbearing, and Spatial Mobility, held in May 2006 at the Max Planck Institute for Demographic Research in Rostock.

Before we proceed with a description of the articles, let us briefly review previous research in the area in order to gain a deeper understanding of how the studies in this special collection contribute to the research field. We focus on the relationship between childbearing and spatial mobility, a subject that has been a major focus in the literature.

\section{Previous research on interdependencies between family events and migration}

\subsection{The effect of family change on internal migration and residential mobility}

Research that looks at the effect of family change on geographical mobility has a long history (Rossi 1955, Long 1972). Studies that are based on longitudinal data and apply event-history analysis, however, have only emerged over the past three decades, along with developments in life-course research. In their path-breaking study, Sandefur and Scott (1981) examined the effect of age, family, and employment variables on the intercounty and inter-state migration of pre-war birth cohorts in the U.S. Their analysis shows that married individuals have lower rates of migration than do singles, and that the rates of migration decrease significantly as family size increases. The authors conclude that two factors are responsible for this reduction. First, the economic cost of a move increases as the number of persons living in a family unit rises. Second, and more 
importantly, the presence of additional members in the family means that more ties must be broken at the place of origin and established at destination.

Courgeau (1989) examined the interrelations between family formation and spatial mobility in France. He extended previous research by making a distinction between the effect of family change on rural-urban and urban-rural migrations. The analysis reveals that married individuals have a lower probability to move than do singles (particularly to the cities), but that the effect of childbearing varies across destinations. The probability of moving to cities decreases significantly after each successive birth, while that of moving to rural areas increases slightly with growing family size. Later, Baccaïni and Courgeau (1996) studied whether or not, and if so, how the impact of childbearing on migration varies over time since childbirth, using register data on the Norwegian post-war cohorts. The analysis shows a low probability of inter-regional migration following a second birth, while the risk of moving from one region to another is relatively high in the year after the first birth, and thereafter rapidly decreases. However, these are net effects as the authors did not distinguish between the impacts of childbearing across migration destination.

The literature has produced some further studies that investigate the effect of childbearing on internal migration. White et al. (1995) focused on the interplay between childbearing and migration in Peru. Although placed into a different context, their analysis to a large extent supports the previous results on the 'average' effect of fertility on migration - the larger the family, the lower the risk of moving from one settlement to another. Again, the authors attribute this to the fact that the cost of relocating a larger family, including some children who may be of school age, is greater. Lindgren (2003), in turn, studied the determinants of urban-rural migration ('counter-urban' moves), using Swedish register data. The analysis shows that rural-bound mobility rises with the birth of a child, whatever the city of residence. The author concludes that the couples may have perceived the arrival of a new family member as the right time to leave the city for a more pleasant environment in the countryside - a move that may have been planned for a long time. Recently, Kulu (2007) observed similar patterns for post-war cohorts in Austria: Overall, the birth of a second and third child reduces the risk of moving from one settlement to another; however, they significantly increase the likelihood of couples to leave large cities for rural areas.

We now turn to the literature on residential mobility. Clark et al. (1984) examined the determinants of residential mobility in the city of Tilburg in the Netherlands. Their analysis shows that the addition of a child stimulates owners as well as renters in the private and public sector to move within the city. The authors attribute this to adjustments in housing consumption. Courgeau (1985) reached very similar conclusions. His study on spatial mobility of pre-war birth cohorts in France indicates that the birth of a child significantly increases the propensity to move. Similarly, the 
author attributes the observed mobility patterns to the need of young married couples to adjust their dwelling size to their family size. A further analysis reveals that some moves were undertaken in anticipation of an increase in family size.

More recently, the effect of family size and childbearing on moving to different housing types, especially to home ownership, has received attention. Deurloo et al. (1994) studied the effect of family change on tenure change in the U.S. The analysis shows that the transition from being a couple to being a family significantly increases the propensity to move into owner-occupied housing. Davies Withers (1998) observed similar patterns in her study on the impact of household transitions to housing transitions. Compared to singles, individuals living in couple and nuclear households are less likely to move within the rental sector, while they are more likely to move to home ownership, especially those in nuclear households. She concludes that transitions to ownership are related to transitions to relatively stable household types: couples and especially families with children. A comparative study by Mulder and Wagner (1998) on West Germany and the Netherlands supports the observation that transition to home ownership is connected with events in the family-life course: marriage, first childbirth when it occurs close to marriage formation, and second childbirth. This connection is stronger in Germany than it is in the Netherlands, where, as the authors argue, home ownership is increasingly pursued by childless couples, probably often in anticipation of having children. The subsequent study by Feijten and Mulder (2002) confirms that Dutch couples increasingly move into a single-family dwelling before the child is born, often during the pregnancy.

The major findings of previous research can thus be summarised as follows. First, childbearing is an important trigger of housing- and environment-related moves. These are mostly moves within a labour-market area or they are migrations from urban regions to surrounding suburban or rural areas. The need for additional space or the desire to live in a more pleasant environment to raise the children in are major determinants of why families decide to change their residence. Second, growing family size reduces the chances of couples to make job-related long-distance moves, especially to urban destinations. The major reason seems to be that the economic and psychological costs of moving from one region to another rise as the family grows, especially when some children are of school age.

We have reviewed the research on the effect of childbearing on migration and residential mobility, but the literature also has produced research on the impact of marital status on spatial mobility. Most studies show that married individuals have a lower propensity to move than singles, particularly over long distances (Sandefur and Scott 1981, Courgeau 1985, 1989, Speare and Goldscheider 1987). Mulder and Wagner (1993) explored the source of mobility differences between single and married persons in more detail, using retrospective data on the German post-war cohorts. The 
examination of the timing of residential changes with respect to partnership changes shows that much of the high mobility of single individuals is attributed to moves related to marriage. When controlling for marriage moves, singles still have a significantly higher propensity to move over long distances, but they have a lower probability to move over short distances.

\subsection{The effect of migration on childbearing}

While the findings described above concerning the effect of childbearing on geographical mobility are as expected (if not self-evident), the question whether or not, and if so, how a move from one place to another shapes the fertility patterns of migrants has given rise to strong debate in the demographic literature. Previous research has proposed four competing views on an individual's fertility following a move from one social context to another (Hervitz 1985, Rundquist and Brown 1989, Lee 1992, Kulu 2005). Each view has received support, but has also been challenged by the literature.

The socialisation hypothesis relies on the assumption that the fertility behaviour of migrants reflects the fertility preferences and behaviour dominant in their childhood. Therefore, migrants exhibit fertility levels similar to non-migrants at origin and a convergence towards the fertility levels of the population at destination occurs only in the next generation (when there is a difference between places). The adaptation hypothesis, by contrast, assumes that it is an individual's current social context rather than the childhood environment that matters most. The hypothesis suggests that migrants, sooner or later, adapt to the fertility behaviour dominant in the destination environment. The selection hypothesis, in turn, argues that behavioural change is not at question, rather that migrants are a special group of people whose fertility preferences are more similar to the preferences of people at destination than at origin. Finally, the disruption hypothesis suggests that immediately following migration, migrants show particularly low levels of fertility due to the disruptive factors associated with the migration process.

While contradictory conclusions of studies often arise because different historical periods, social contexts, and types of migration are investigated, the dependence on cross-sectional data of studies concerning migrant fertility has significantly limited the possibilities to clarify which of the four views is true in the respective context and for the behaviour of particular migrant groups. Research based on longitudinal data has only emerged in the last two decades and mostly in studies of the fertility of internal migrants. In a pioneering study, Courgeau (1989) examined the fertility of rural-urban and urban-rural migrants in France, using retrospective life-history data for pre-war birth cohorts. His analysis showed that migration to the city significantly reduces a 
woman's fertility, whereas migration to rural settlements increases it. A further analysis reveals that migration to rural areas attracted women, whose pre-move fertility was similar to that of other women in the urban area, whereas migration to urban areas attracted women whose fertility was similar to that prevailing in the urban areas. Thus, urban-rural migrants adapt to the behaviour dominant in the rural areas, while ruralurban migrants are a selected group, according to their fertility preferences. White et al. (1995) also found evidence supporting the selection hypothesis in an analysis of the fertility of internal migrants in Peru. More specifically, new residents living in larger locations in general and in the capital city in particular, are more likely to arrive with lower lifetime fertility preferences.

The most recent studies have supported the adaptation hypothesis, contributing to the discussion on migrant selectivity. Lindstrom (2003) studied the fertility of ruralurban migrants in Guatemala and found that they had fertility levels close to natives in urban areas, particularly for higher-order births, suggesting that rural-urban migrants adapt to urban fertility practices. The analysis also reveals that rural-urban migrants display elevated first-birth risks following migration, and the author attributed this to the fact that migration, marriage, and the start of childbearing are closely connected events in Latin America. Kulu $(2005,2006)$ observed very similar patterns in the European context. His study of Austrian, Estonian, and Polish post-war birth cohorts shows that in the three countries people living in urban areas in general and in the large cities in particular have a lower fertility than those living in rural settlements, and that people who move from one place to another exhibit fertility levels similar to those of natives at destination. While elevated first-birth risks are observed for women who move because of union formation, the analysis shows no (unobserved) selectivity of migrants by long-term fertility plans. Similarly, Jensen and Ahlburg (2004) found little evidence of migrant selectivity by fertility preferences in their study on migrant fertility in Philippines. The analysis reveals that rural-urban migrants exhibit fertility levels close to non-migrants in urban areas.

A close connection between migration and family formation has also been demonstrated in those few studies on fertility of international migrants that are based on longitudinal data. Singley and Landale (1998) compared the risk of first birth of several groups of Puerto Rican women: born in Puerto Rico, but residing in the U.S., residing in Puerto Rico, and the U.S.-born Puerto Ricans. Their analysis reveals that single women migrating to the U.S. are much more likely than their non-migrant counterparts in Puerto Rico to form unions and to conceive, either within or without union. The authors conclude that migration to the U.S. should be seen as part of the familybuilding process for many Puerto Rican women. Andersson (2004) arrives at very similar conclusions when examining immigrant fertility in Sweden. His analysis of the risk of a first birth shows elevated levels of childbearing during the first few years after 
immigration to Sweden. Moreover, he found migration to trigger childbearing to higher birth orders, too. In contrast, the fertility levels of immigrants who had lived in Sweden for a period of at least five years were similar to the levels of the Swedish-born population, a finding that supports the idea of relatively rapid adaptation of the childbearing behaviour to that prevailing in the country of destination.

This concludes our review of the earlier literature. We now turn to the eleven articles that make up this Special Collection of Demographic Research.

\section{The contributions to the Special Collection of Demographic Research}

Over the last few decades, the life trajectories of individuals have become less conventional, patterned, and predictable (Konietzka and Huinink 2003). More generally, as many researchers argue, the structure of the life course has changed in profound ways, becoming 'de-standardized', 'de-institutionalized', and increasingly 'individualized' (see, e.g. Macmillan 2005). Increasing diversity in family, educational, and employment careers suggests that the spatial mobility patterns of individuals also have become more complex over time. This is the context of the first two papers. Clark and Davies Withers (2007) examine the long- and short-distance moves of couples and families living in the U.S. Using data from the Panel Study of Income Dynamics, they show that the connection between employment, family changes, and housing considerations, on the one hand, and migration and residential mobility, on the other, has indeed become more complex. Changes in occupational aspirations still do explain many long-distance moves, and changes in a family's interaction with the housing market still account for the majority of residential changes over short distances. However, housing considerations play an increasing role in long-distance moves, too, as do employment issues in short-distance residential changes. Moreover, the study reveals the increasing importance of unplanned moves over short and long distances, many of which result from the disruption of cohabitational or marital unions.

Feijten and van Ham (2007) continue to develop this issue, examining the spatial mobility of separated people. While it is clear that at least one of the partners has to leave the joint home in the process of separation, little is known about spatial mobility patterns of people after separation. Combining the data of two retrospective surveys from the Netherlands, the authors find that separated people move more often than singles or families, particularly in the first years after separation. As expected, most moves are over short distances and they are obviously related to housing adjustment after separation and a subsequent move. Interestingly, however, separated fathers tend to have the shortest moving distances of all, which suggests that men prefer to stay 
geographically close to their children, who usually stay with the mother following separation. While the study is another good example of the increasing complexity of spatial-mobility patterns, it provides clear evidence on how 'linked lives' influence people's residential choices.

The next two papers make the role of 'linked lives' in residential choices the main focus by examining the distances between adult children and their parents. Michielin and Mulder (2007) argue that non-resident family members constitute an essential part of an individual's social capital, and that their presence increases the value associated with a specific location. Families with small children seek their (grand)parents to play a supportive role, whereas parents with health problems may need their children's help and support. Using data from the Netherlands Kinship Panel Study, the authors show that families with children, divorced individuals, and individuals with health problems have the shortest distance to parents. This suggests that family members indeed constitute an important 'location-specific capital' at a certain life stage and for certain population subgroups. Interestingly, however, the need to support the younger rather than the older generation seems to be the main determinant of the distance between adult children and their parents.

Malmberg and Pettersson (2007) continue with the topic, providing an analysis of Swedish register data that cover the country's entire population. The analysis shows that the distances between adult children and their parents in Sweden are not as large as one may have expected: A total of $85 \%$ of parents live within commuting distance of their adult children; the corresponding figure for their adult children is $72 \%$. Moreover, the study shows that the patterns have remained consistent over time, thus challenging the assumption that in countries that have strong welfare institutions and weakened family ties, the distances between adult children and their parents have increased. A further analysis reveals some variation in child-parent distances by gender and education. Men live closer to their parents at younger ages, while women tend to do so when the parents are old, thus confirming that daughters are more engaged in the contact with and care of elderly parents at a late stage in their life. Highly educated individuals, in turn, have the longest distances to their parents, reflecting the fact that people with a university degree are employed in more dispersed labour markets.

While the first four papers in this Special Collection focus on the effect of family change on spatial mobility and residential choices, the next four articles look at the fertility and family patterns of internal migrants. Gabrielli, Paterno, and White (2007) examine the impact of interregional migration on first-birth propensities in Italy. Whereas in Italy, fertility variation across regions has decreased over time, significant differences persist. Similarly, South-North migration continues to be an important source of population redistribution in the country, although to a smaller extent than in the 1950s and 1960s. Using the data from two longitudinal studies, the authors find that 
women in Southern Italy have a higher propensity of a first birth than those who live in the Centre or Northern regions of the country, and that migrants, particularly those moving from the South to the North, exhibit significantly higher fertility levels than non-migrants. The regional fertility variation persists after controlling for demographic and socio-economic characteristics of women, while the differences between migrants and stayers disappear, suggesting that much of the initial fertility variation can be attributed to selective migration, particularly to moves related to marriage. Interestingly, however, migrants from the South have a higher fertility than nonmigrants at destination even after controlling for the migrant selectivity. The study thus confirms the close connection between migration and family formation, but also shows that women from Southern Italy tend to maintain their distinct fertility patterns in new locations.

Nedoluzhko and Andersson (2007) provide a similar analysis of migrant fertility within a Central Asian context. The analysis of retrospective survey data from Kyrgyzstan shows that people who move from one settlement to another exhibit significantly higher first-birth propensities than those who do not move. Fertility levels are particularly high for women in the first year after migration and for those who move to rural areas and small towns. Again, a further analysis reveals that elevated fertility levels shortly after migration are attributed to the fact that many migrations, particularly towards smaller settlements, are marriage-related. The study provides another convincing example of the close connection between internal migration and family formation, and underlines the importance of the careful investigation of the timing of family changes relative to migration in order to gain a deeper understanding of the causes of migrant fertility patterns.

The timing and selectivity issues also occupy a central position in a paper authored by Kulu and Vikat (2007), which examines fertility variation across housing types and childbearing patterns following housing changes. While it is not surprising that family events are important triggers of housing transitions, it has been less clear to what extent a change in housing or in housing conditions shapes childbearing patterns. Using longitudinal register data from Finland, the authors find a significant variation in fertility levels across housing types - fertility is highest among couples living in singlefamily houses and lowest among couples residing in apartments. However, a further analysis reveals elevated fertility levels after couples have changed housing, suggesting that much of the fertility variation across housing types is attributed to selective moves. Still, a relatively high third-birth propensity for couples in single-family houses several years after the move suggests that living in spacious housing and in a family-friendly environment for a longer time leads to higher fertility.

Muszynska and Kulu (2007) extend the research field by investigating the effect of long-distance moves on union dissolution. Previous studies show that family migration 
is usually to the benefit of the man's career and has a negative impact on the woman's professional career and earnings (Boyle et al. 2003). If a woman's economic well-being suffers from family migration, one may expect that migration also exerts a negative influence on the quality of the relationship between the partners. Hence, the propensity of union disruption may increase. The analysis of the data of two retrospective surveys on Russia shows that family migration indeed raises union instability: Couples who move frequently over long distances have a significantly higher risk of union dissolution than couples who do not move or move only once. Interestingly, however, the study shows that frequent migrants had a high risk of union dissolution in the Soviet period but not so during the post-Soviet socio-economic transition. The authors attribute this finding to the dramatically reduced employment opportunities during the economic recession and to the diminished opportunities for tied migrants to leave a partnership that had become unsatisfactory after frequent moves.

The last three papers in this Special Collection focus on international migration and childbearing - a research subfield that is of increasing importance. Lindstrom and Giorguli Saucedo (2007) study interrelations between fertility and migration from Mexico to the U.S., which is one of the largest migration systems in the world. Analysing the data on married couples collected by the Mexican Migration Project, they show that for Mexican men the likelihood of migration to the U.S. is greatest in the years during which a birth took place and that it increases with birth order. For women, by contrast, the propensity of migration decreases progressively with each additional birth. The authors argue that a highly gendered family-role specialisation in Mexico pulls young mothers into the home to assume the tasks of childcare and pushes men into U.S. labour markets, where the economic returns on men's labour are the greatest. The analysis of fertility patterns of migrants shows that women who move to the U.S. exhibit significantly higher first-birth risks than women who stay in Mexico, but lower second- and third-birth propensities. While elevated first-birth levels support the contention that migration and family formation are often connected events, and that a child born in a destination country is believed to strengthen the legal status of parents there, the low second- and third-birth levels indicate that women who move to the U.S. rapidly adopt the lower fertility practices dominant in the U.S., although the selectivity of migrants may also play a role.

Milewski (2007) continues on this topic by examining family formation among post-war labour migrants and their descendants in West Germany. Previous research has examined economic, political, and cultural activities of 'guest workers' and their descendants in Western Europe, while their family and fertility dynamics have received less attention. Using data from the German Socio-Economic Panel Study, the author shows that immigrant women exhibit significantly higher first-birth propensities than 'native Germans', and that their fertility levels are elevated shortly after arrival in 
Germany. The fertility differences between the natives and migrants decrease after controlling for migrant selectivity by marital status and labour-market characteristics, but they remain significant. The study provides another good example that international migration, marriage, and first birth often are parts of the same (family formation) process. However, the study also suggests that having a child after migration strengthens the position of immigrant women embedded in a traditional family setting, particularly when employment perspectives are poor, which for marriage-migrants is the rule rather than an exception. Additionally, the study shows that the fertility patterns of the descendants of immigrants are similar to those of Germans, reflecting the fact that they adapt (or assimilate) to the German context.

Finally, Andersson and Scott (2007) examine the effect of the labour-market status on the childbearing of the native- and foreign-born population in Sweden. Many studies in Western Europe and in the U.S. show a negative correlation between women's labour-market participation and childbearing. Previous research on Sweden, by contrast, has revealed a positive association between employment and motherhood in the institutional context where childrearing and employment are more easily compatible and where childcare benefits are based on the prior earnings of mothers (Andersson and Scott 2005). Analysing Swedish register data, the authors show that a similar positive, although weaker, association between labour-market attachment and fertility exists also for the propensities of having a second and third child. Moreover, the effect of employment on fertility is similar for Swedish- and foreign-born populations, something the authors attribute to the equalising effects of the Swedish welfare state. Interestingly however, the study also reveals that immigrant women from (most) highfertility countries (Somalia, Turkey, and Vietnam) have significantly higher secondand third-birth propensities than Swedish-born women, thus providing evidence for socialisation effects along with adaptation/assimilation processes, which become visible when one examines transitions to a higher-order parity.

\section{Conclusion}

As editors of this Special Collection of Demographic Research, we believe that the contributions provide clear evidence on how research based on the life-course perspective and on event-history analysis advances our knowledge of the interplay between family and fertility behaviour of individuals, on the one hand, and their migration and residential mobility, on the other. We have gained a deeper understanding of some old issues (i.e., migrant fertility, particularly in first-birth patterns) and we also now know much more about emerging new phenomena in contemporary industrialised societies (i.e., the interaction between migration and union 
dissolution). What follows is a brief discussion of some issues raised in the papers and of opportunities for further research.

Several of the papers have found elevated first-birth levels shortly after migration, attributing the phenomenon to the close connection between migration, union formation, and childbearing. As marriage-related migration forms a significant portion of (contemporary) international and internal migration, the findings meet expectations. However, only a careful examination of the timing of fertility with respect to migration and marriage enables us to detect the patterns. We believe that further research on the fertility of marriage-migrants is a way ahead. While it is not surprising that women who marry and move have high first-birth levels, the question still remains whether or not they exhibit higher fertility levels than women who marry and do not move (or who change a residence locally only). Two papers on immigrant fertility suggest that immigrant women have a child shortly after migration (and marriage), among other factors because they wish to secure their legal status in the country of destination and strengthen their position in a traditional family setting (cf. Bledsoe 2004). Similarly, women who move for marriage from one settlement to another within a country may decide to have a child soon because motherhood increases their 'symbolic capital' and 'justifies' their existence in the new social setting, particularly when employment perspectives are not promising. Alternatively, women may decide to have a child shortly after migration to fill in time during the adjustment period, i.e., when the employment career is disrupted (anyway), old social networks are broken, and new ones have yet to be established.

Marriage-migrants make up a significant share of migrants and their first-birth patterns determine those of all migrants, thus possibly masking the childbearing behaviour of other groups. Future research would benefit from explicit examination of first-birth patterns of other migrant groups, too, particularly childless couples or single persons who move from one place or country to another for a variety of reasons. Obviously, on some occasions the selectivity effects also play a role here (e.g., settlement changes with the intention to have a child), making it more difficult to tease out the net effect on fertility of migration and a change of context. Additionally, as different factors may operate and be visible at different times during the life-course of migrants, a careful examination of childbearing by parity is an important (if not a mandatory) part of the analysis, too. It seems that only patterns of second or third birth eventually reveal whether adaptation effects dominate over socialisation ones in a particular context or for a particular migrant group.

Finally, we wish to emphasise that an examination of the fertility patterns of migrants is not an end in itself or that it is important only when migrants significantly shape the fertility patterns of a region or a country. Rather, we argue that an investigation of the childbearing of migrants, particularly those moving from one 
country to another, is a promising way along with other ways (see Hoem 1990, 1993b, Neyer and Andersson 2007) to find short- and long-term effects of changing socioeconomic, cultural, and institutional contexts on fertility behaviour. Comparative research in the European context is particularly promising as it offers a unique opportunity to explore how societal contexts and public policies shape the childbearing patterns of migrants. A challenge for research on migrant fertility, however, will be how to integrate better the findings into the wider literature on fertility determinants.

On the migration side, the studies in this Special Collection have shown increasing complexities of migration patterns within contemporary industrialised societies and emerging new forms of migration as a result of changes in family patterns. The studies have also suggested the need to go beyond conventional migration models, including information on the life trajectories of non-resident family members (adult children or elderly parents) in the analysis of the migration decisions of individuals or (nuclear) families. The research on international migration has for a long time, and in different ways, emphasised the importance of social networks and capital for individuals' decision to move from one country to another and for their choice of location at destination. However, the concept of 'linked lives' extends the horizon by suggesting the need to examine the interplay between the life trajectories of individuals and of their 'significant others' over the entire life course. As suggested and demonstrated, parents may be an important 'location-specific capital' for adult children when their children are small, while adult children, particularly daughters, may be the same for their parents when they have reached the ages at which health problems become a main issue. The life trajectories of non-resident family members may thus be of critical importance when one analyses decisions to move or to stay. Looking at the issue from the perspective of fertility research, the availability or unavailability of daily parental support, in turn, may have an impact on childbearing decisions.

Finally, the interdependencies of family change and migration in the life course of individuals would need an explicit investigation. Most papers in this collection focus either on migration or on family changes in the life course and their authors treat family or migration, correspondingly, as an important 'parallel career' that shapes the main trajectory of interest. However, the study on migration and childbearing patterns of Mexicans in Mexico and in the U.S. demonstrates how an examination of the interaction between the two processes leads us to gain a deeper understanding of people's family and migration decisions. From an analytical point of view, an investigation of the interdependencies of the careers is related to further complexities in the data analysis, but recent advances in event-history analysis provide us with the tools to handle the raising issues (Lillard 1993, Brien et al. 1999, Mulder and Wagner 2001, Hoem and Kreyenfeld 2006). The ultimate aim is nothing less than to provide a deeper understanding of how individuals, being 'agents in the social context', simultaneously 
structure their family lives and residential and other trajectories, and how demographic change is shaped in society.

\section{Acknowledgements}

We deeply appreciate input from Jan M. Hoem, his advice and encouragements. We also express our sincerest gratitude to Clara Mulder and to other members of the Scientific Review Board of Demographic Research for valuable comments and suggestions, which helped the authors of this volume to revise their manuscripts. We are grateful to Renée Flibotte-Lüskow and Jana Tetzlaff for having organised the peerreview of the manuscripts, and to Manuela Schicka for having prepared the layout of the papers. We thank Susann Backer and an anonymous reviewer for having language edited the manuscripts. 


\section{References}

Andersson, G. 2000. The impact of labour-force participation on childbearing behaviour: pro-cyclical fertility in Sweden during the 1980s and the 1990s, European Journal of Population 16(4): 293-333.

Andersson, G. 2004. Childbearing after migration: fertility patterns of foreign-born women in Sweden, International Migration Review 38(1): 364-392.

Andersson, G., and K. Scott. 2005. Labour-market status and first-time parenthood: the experience of immigrant women in Sweden, 1981-97, Population Studies 59(1): 21-38.

Andersson, G., and K. Scott. 2007. Childbearing dynamics of couples in a universalistic welfare state: The role of labor-market status, country of origin, and gender, Demographic Research 17(30): 897-938. www.demographic-research.org/ Volumes/Vol17/30/default.htm.

Baccaïni, B., and D. Courgeau. 1996. The spatial mobility of two generations of young adults in Norway, International Journal of Population Geography 2: 333-359.

Billari, F. 2005. Life course analysis: two (complementary) cultures? Some reflections with examples from the analysis of the transition to adulthood, in R. Levy, P. Ghisletta, J.-M. Le Goff, D. Spini and E. Widmer (Eds.), Towards an Interdisciplinary Perspective on the Life Course. Oxford: Elsevier, pp. 261-282.

Bledsoe, C. H. 2004. Reproduction at the margins: migration and legitimacy in the New Europe, Demographic Research S3(4): 87-116. http://www.demographicresearch.org/special/3/4/default.htm.

Blossfeld, H.-P., and G. Rohwer. 1995. Techniques of Event History Modeling: New Approaches to Causal Analysis. Mahwah: Lawrence Erlbaum Associates.

Bourdieu, P. 1977. Outline of a Theory of Practice. Cambridge: Cambridge University Press.

Boyle, P. J., T. J. Cooke, K. Halfacree, and D. Smith. 2003. The effect of long-distance family migration and motherhood on partnered women's labour market activity rates in GB and the US, Environment and Planning A 35: 2097-2114.

Brien, M. J., L. A. Lillard, and L. J. Waite. 1999. Interrelated family-building behaviors: cohabitation, marriage, and nonmarital conception, Demography 36(4): 535-551. 
Castles, S., and M. J. Miller. 1998. The Age of Migration: International Population Movements in the Modern World. Second edition. London: Macmillan.

Clark, W. A. V., and S. Davies Withers. 2007. Family migration and mobility sequences in the United States: Spatial mobility in the context of the life course, Demographic Research 17(20): 591-622. www.demographic-research.org/ Volumes/Vol17/20/default.htm.

Clark, W. A. V., M. C. Deurloo, and F. M. Dieleman. 1984. Housing consumption and residential mobility, Annals of the Association of American Geographers 74(1): $29-43$.

Courgeau, D. 1985. Interaction between spatial mobility, family and career life-cycle: a French survey, European Sociological Review 1(2): 139-162.

Courgeau, D. 1989. Family formation and urbanization, Population: An English Selection 44(1): 123-146.

Courgeau, D. 1997. New methodological approaches in the social science: a general overview, Population 54(2): 1-9.

Courgeau, D., and É. Lelièvre. 1989. Analyse Demographique des Biographies. Paris: Institut national d'études démographiques.

Courgeau, D., and É. Lelièvre. 1997. Changing paradigm in demography, Population: An English Selection 9: 793-801.

Courgeau, D., and B. Baccaïni. 1998. Multilevel analysis in the social science, Population: An English Selection 10(1): 39-71.

Cox, D. R. 1972. Regression models and life-tables, Journal of the Royal Statistical Society B 34(2): 187-220.

Davies Withers, S. 1998. Linking household transitions and housing transitions: a longitudinal analysis of renters, Environment and Planning A 30: 615-630.

Détang-Dessendre, C., and I. Molho. 1999. Migration and changing employment status: a hazard function analysis, Journal of Regional Science 39(1): 103-123.

Deurloo, M. C., W. A. V. Clark, and F. M. Dieleman. 1994. The move to housing ownership in temporal and regional contexts, Environment and Planning A 26(11): 1659-1670.

Duncan, G. J., and J. N. Morgan 1985. The panel study of income dynamics, in G. H. Elder, Jr. (Ed.), Life Course Dynamics: Trajectories and Transitions, 19681980. Ithaca: Cornell University Press, pp. 50-71. 
Dykstra, P. A., and L. J. G. van Wissen. 1999. Introduction: the life course approach as an interdisciplinary framework for population studies, in L. J. G. van Wissen and P. A. Dykstra (Eds.), Population Issues: An Interdisciplinary Focus. New York: Plenum Press, pp. 1-22.

Elder, Jr., G. H. 1985a. Preface, in G. H. Elder, Jr. (Ed.), Life Course Dynamics: Trajectories and Transitions, 1968-1980. Ithaca: Cornell University Press, pp. $15-20$.

Elder, Jr., G. H. 1985b. Perspective on the life course, in G. H. Elder, Jr. (Ed.), Life Course Dynamics: Trajectories and Transitions, 1968-1980. Ithaca: Cornell University Press, pp. 23-49.

Elder, Jr., G. H. 1994. Time, human agency, and social change: perspective on the life course, Social Psychology Quarterly 57(1): 4-15.

Elster, J. 1989. Nuts and Bolts for the Social Sciences. Cambridge: Cambridge University Press.

Esping-Andersen, G. 1990. The Three Worlds of Welfare Capitalism. Princeton: Princeton University Press.

Feijten, P., and C. H. Mulder. 2002. The timing of household events and housing events in the Netherlands: a longitudinal perspective, Housing Studies 17(5): 773-792.

Feijten, P., and M. van Ham. 2007. Residential mobility and migration of the divorced and separated, Demographic Research 17(21): 623-654. www.demographicresearch.org/Volumes/Vol17/21/default.htm.

Gabrielli, G., A. Paterno, and M. White. 2007. The impact of origin region and internal migration on Italian fertility, Demographic Research 17(24): 705-740. www.demographic-research.org/Volumes/Vol17/24/default.htm.

Giddens, A. 1984. The Constitution of Society: Outline of the Theory of Structuration. Cambridge: Polity Press.

Giele, J. Z., and G. H. Elder, Jr. 1998. (Eds.) Methods of Life Course Research: Qualitative and Quantitative Approaches. Thousand Oaks: Sage Publications.

Giele, J. Z., and G. H. Elder, Jr. 1998. Life course research: development of a field, in J. Z. Giele and G. H. Elder, Jr. 1998. (Eds.), Methods of Life Course Research: Qualitative and Quantitative Approaches. Thousand Oaks: Sage Publications, pp. 5-27. 
Hervitz, H. M. 1985. Selectivity, adaptation, or disruption? A comparison of alternative hypotheses on the effects of migration on fertility: the case of Brazil, International Migration Review 19(2): 293-317.

Hoem, J. M. 1970. Probabilistic fertility models of the life table type, Theoretical Population Biology 1: 12-38.

Hoem, J. M. 1987. Statistical analysis of a multiplicative model and its application to the standardization of vital rates: a review, International Statistical Review 55(2): 119-152.

Hoem, J. M. 1990. Social policy and recent fertility change in Sweden, Population and Development Review 16(4): 735-748.

Hoem, J. M. 1993a. Classical demographic models of analysis and modern eventhistory techniques, IUSSP: 22nd International Population Conference, Montreal, Canada, Volume 3, pp. 281-291.

Hoem, J. M. 1993b. Public policy as the fuel of fertility: effects of a policy reform on the pace of childbearing in Sweden in the 1980s, Acta Sociologica 36(1): 19-31.

Hoem, J. 1997. Educational gradients in divorce risks in Sweden in recent decades, Population Studies 51(1): 19-27.

Hoem, J. 2007. Demography, present and future, Population: An English Selection 62(1): 53-56.

Hoem, J. M., and M. Kreyenfeld. 2006. Anticipatory analysis and its alternatives in lifecourse research, part 2: marriage and first birth, Demographic Research 15(17): 485-498. http://www.demographic-research.org/Volumes/Vol15/17/default.htm.

Hoem, J. M., G. Neyer, and G. Andersson. 2006a. Education and childlessness: the relationship between educational field, educational level, and childlessness among Swedish women born in 1955-59, Demographic Research 14(15): 331-380. http://www.demographic-research.org/Volumes/Vol14/15/default.htm.

Hoem, J. M., G. Neyer, and G. Andersson. 2006b. Educational attainment and ultimate fertility among Swedish women born in 1955-59, Demographic Research 14(16): 381-404. http://www.demographic-research.org/Volumes/Vol14/16/ default.htm.

Hollis, M. 1996. Philosophy of social science, in N. Bunnin and E. P. Tsui-James (Eds.), The Blackwell Companion to Philosophy. Oxford: Blackwell Publishers, pp. 358-387. 
Jensen, E. R., and D. A. Ahlburg. 2004. Why does migration decrease fertility? Evidence from the Philippines, Population Studies 58(2): 219-231.

Kantorová, V. 2004. Education and entry into motherhood: the Czech Republic during state socialism and the transition period (1970-1997), Demographic Research S3(10): 245-274. www.demographic-research.org/special/3/10/default.htm.

Konietzka, D., and J. Huinink. 2003. Die De-Standardisierung einer Statuspassage? Zum Wandel des Auszugs aus dem Elternhaus und des Übergangs in das Erwachsenenalter in Westdeutschland, Soziale Welt 54: 285-312.

Kravdal, Ø. 2001. The high fertility of college educated women in Norway: an artefact of the separate modelling of each parity transition, Demographic Research 5(6): 185-216. http://www.demographic-research.org/Volumes/Vol5/6/default.htm.

Kreyenfeld, M. 2002. Time-squeeze, partner effect or self-selection? An investigation into the positive effect of women's education on second birth risks in West Germany, Demographic Research 7(2): 13-48. www.demographicresearch.org/Volumes/Vol7/2/default.htm.

Kulu, H. 2005. Migration and fertility: competing hypotheses re-examined, European Journal of Population 21(1): 51-87.

Kulu, H. 2006. Fertility of internal migrants: comparison between Austria and Poland, Population, Space and Place 12(3): 147-170.

Kulu, H. 2007. Fertility and spatial mobility in the life course: evidence from Austria, Environment and Planning A (advance online publication).

Kulu, H., and F. C. Billari. 2006. Migration to urban and rural destinations in postSoviet Estonia: a multilevel event-history analysis, Environment and Planning 38(4): 749-764.

Kulu, H., and A. Vikat. 2007. Fertility differences by housing type: The effect of housing conditions or of selective moves?, Demographic Research 17(26): 775802. www.demographic-research.org/Volumes/Vol17/26/default.htm

Lee, B. S. 1992. The influence of rural-urban migration on migrant's fertility behavior in Cameroon, International Migration Review 26(4): 1416-1447.

Leisering, L., and K. F. Schumann. 2003. How institutions shape the German life course, in W. R. Heinz and V. W. Marshall (Eds.), Social Dynamics of the Life Course. New York: Walter de Gruyter, pp. 193-210. 
Lillard, L. A., 1993, Simultaneous equations for hazards: marriage duration and fertility timing, Journal of Econometrics 56(1-2): 189-217.

Lindgren, U. 2003. Who is the counter-urban mover? Evidence from the Swedish urban system, International Journal of Population Geography 9: 399-418.

Lindstrom, D. P. 2003. Rural-urban migration and reproductive behaviour in Guatemala, Population Research and Policy Review 22(4): 351-372.

Lindstrom, D. P., and S. Giorguli Saucedo. 2007. The interrelationship of fertility, family maintenance, and Mexico-U.S. migration, Demographic Research 17(28): 821-858. www.demographic-research.org/Volumes/Vol17/28/default. htm.

Long, L. H. 1972. The influence of number and ages of children on residential mobility, Demography 9(3): 371-382.

Macmillan, R. 2005. The structure of the life course: classic issues and current controversies, in R. Macmillan (Ed.), The Structure of the Life Course: Standardized? Individualized? Differentiated? Oxford: Elsevier, pp. 3-24.

Malmberg, G., and A. Pettersson. 2007. Distance to elderly parents: Analyses of Swedish register data, Demographic Research 17(23): 679-704. www.demographic-research.org/Volumes/Vol17/23/default.htm.

Mayer, K. U., and N. B. Tuma. 1990. (Eds.) Event History Analysis in Life Course Research. Madison: The University of Wisconsin Press.

Marshall, V. W., and M. M. Mueller. 2003. Theoretical roots of the life-course perspective, in W. R. Heinz and V. W. Marshall (Eds.), Social Dynamics of the Life Course. New York: Walter de Gruyter, pp. 3-32.

Massey D, S., and K. E. Espinosa. 1997. What's driving Mexico-U.S. migration? A theoretical, empirical, and policy analysis, American Journal of Sociology 102(4): 939-999.

Michielin, F. and C. H. Mulder. 2007. Geographical distances between adult children and their parents in the Netherlands, Demographic Research 17(22): 655-678. www.demographic-research.org/Volumes/Vol17/22/default.htm.

Milewski, N. 2007. First child of immigrant workers and their descendants in West Germany: Interrelation of events, disruption, or adaptation?, Demographic Research 17(29): 859-896. www.demographic-research.org/Volumes/Vol17/29/ default.htm. 
Mulder, C. H., and M. Wagner. 1993. Migration and marriage in the life course: a method for studying synchronized events, European Journal of Population 9(1): $55-76$.

Mulder, C. H., and M. Wagner. 1998. First-time home-ownership in the family life course: a West German-Dutch comparison, Urban Studies 35(4): 687-713.

Mulder, C. H., and M. Wagner. 2001. The connections between family formation and first-time home ownership in the context of West Germany and the Netherlands, European Journal of Population 17(2): 137-164.

Muszynska, M., and H. Kulu. 2007. Migration and union dissolution in a changing socio-economic context: The case of Russia, Demographic Research 17(27): 803-820. www.demographic-research.org/Volumes/Vol17/27/default.htm.

Nedoluzhko, L., and G. Andersson. 2007. Migration and first-time parenthood: Evidence from Kyrgyzstan, Demographic Research 17(25): 741-774. www.demographic-research.org/Volumes/Vol17/25/default.htm.

Neyer, G., and G. Andersson. 2007. Consequences of family policies on childbearing behavior: effects or artifacts? Working Paper WP-2007-021. Rostock: Max Planck Institute for Demographic Research. http://www.demogr.mpg.de/papers/ working/wp-2007-021.pdf.

Öberg, S. 1996. Spatial and economic factors in future South-North migration, in W. Lutz (Ed.), The Future Population of the World: What Can We Assume Today? Revised edition. London: Earthscan, pp. 336 -357.

Rossi P, 1955. Why Families Move. Glencoe: The Free Press.

Rundquist, F.-M., and L. A. Brown. 1989. Migrant fertility differentials in Ecuador, Geografiska Annaler B 71(2): 109-123.

Sandefur, G. D., and W. J. Scott. 1981. A dynamic analysis of migration: an assessment of the effects of age, family and career variables, Demography 18(3): 355-367.

Settersten, Jr., R. A., and L. Gannon. 2005. Structure, agency, and the space between: on the challenges and contradictions of a blended view of the life course, in R. Levy, P. Ghisletta, J.-M. Le Goff, D. Spini and E. Widmer (Eds.), Towards an Interdisciplinary Perspective on the Life Course. Oxford: Elsevier, pp. 35-53.

Singley, S. G., and N. S. Landale. 1998. Incorporating origin and process in migrationfertility frameworks: the case of Puerto Rican women, Social Forces 76(4): $1437-1464$. 
Speare, Jr., A., and F. K. Goldscheider. 1987. Effects of marital status change on residential mobility, Journal of Marriage and the Family 49(2): 455-464.

Wagner, M. 1990. Education and migration, in K. U. Mayer and N. B. Tuma (Eds.), Event History Analysis in Life Course Research. Madison: The University of Wisconsin Press, pp. 129-145.

White, M. L., L. Moreno, and S. Guo. 1995. The interrelation of fertility and geographic mobility in Peru: a hazards model analysis, International Migration Review 29(2): 492-514.

White Riley, M. 1998. A life course approach: autobiographical notes, in J. Z. Giele and G. H. Elder, Jr. (Eds.), Methods of Life Course Research: Qualitative and Quantitative Approaches. Thousand Oaks: Sage Publications, pp. 28-51.

Willekens, F. J. 1999. The life course: models and analyses, in P. A. Dykstra and L. J. G. van Wissen (Eds.), Population Issues: An Interdisciplinary Focus. New York: Kluwer Academic, pp. 23-52.

Wright, E. O. 1997. Class Counts: Comparative Studies in Class Analysis. Cambridge: Cambridge University Press.

Yamaguchi, K. 1991. Event History Analysis. Applied Social Research Methods Series Volume 28. Newbury Park: Sage Publications. 